\title{
Characterization of wastes and their recycling potentials; A case study of East-West Road, Port Harcourt.
}

\author{
*11KONYA, R. S; ZITTE, L. F.; UGWULOR, Q. N. \\ Department of Animal and Environmental Biology, Faculty of Biological Sciences, College of Natural and Applied Sciences, University of \\ Port Harcourt. Nigeria
}

Key words: Solid waste, waste characterization, recycling potentials, waste scavengers

\begin{abstract}
Wastes along the Port Harcourt axis of East -West Road from Choba Bridge to Rumukwurushi tank were studied. This study was based on the characterization of wastes and its recycling potentials. Eight different waste receptacles were studied. Wastes in these receptacles were characterized and their recycling potentials evaluated. Predominant wastes at each receptacle were identified through direct waste sorting and characterization. Waste scavengers were interviewed to appreciate the trend of waste sorting and characterization in Port Harcourt. Common waste discovered at the receptacles were cartons, papers, animals bones, plastics, aluminium plates, nylon bags, ceramic materials, vegetable stems, hospital wastes, old and damaged electronics, old computers, photocopying machines etc. The wastes in the area could be grouped into municipal wastes and they express the type of activities carried out within the study area. Recycling potentials of the characterized wastes were identified and the likely benefits of waste recycling emphasized. It was observed that: plastics could be recycled into fleece jacket; aluminium cans could be shredded, ground and melted to form another aluminium sheet. Bottles, glass and ceramics were observed to be recycleable into their original products. Vegetable stems and garbage could be used to produce compost and animal bones crushed and used to produce vim. Other combustible materials could be used as fuel. Awareness on recycling should generally be encouraged in society. @JASEM
\end{abstract}

DOI: http:/ / dx.doi.org/10.4314/jasem.v17i2.7

Waste is sometimes described as a resource put in a wrong place. Waste is also described as any unwanted material from a manufacturing process US EPA (1995). According to Gulphin (1976), waste is any material of solid or semisolid character that the possessors no longer consider useful.

All our daily activities can give rise to varieties of wastes arising from different sources. There are many items considered as waste items such as household rubbish, sewage sludge, industrial wastes, packaging items, discarded cards, old televisions, garden wastes, old paint containers, glasses etc US EPA (1990). Because of its importance as an integral part of life, it is unavoidable, though it is grossly abhorred. Solid waste is generated in our cities on a daily basis and its economic importance as nuisance stirs up great concern (Lavee 2007). Because of this, its management takes a centre stage in most of our environmental management programmes. As a management strategy, waste is proposed to be converted into a resource by putting some values into what had no value (Daskalopoulus 1998).

Waste management is the collection, transportation, processing, monitoring and reuse of waste. It is also seen as a way to recover resources from wastes. It can involve managing of solid, liquid, or gases. Waste recycling involves a process of characterization, sorting, grading, reduction and reuse of wastes (Bonnie 2006). This chain of activities requires the services of experienced staff to identify and categorize wastes according to its end uses. For example, glass wastes are graded according to colours while plastic wastes are according to its composite textures. Recycling of paper wastes depends on the strained's strengths (US EPA 1990). These different and specific details inform the proper understanding of waste recycling.

It was also observed that different wastes are recycled according to their relative cost as compared to the production of new ones. Plastic recycling suffers poor patronage because it is cheaper to produce a new plastic product than to recycle used ones while glass, aluminium and paper recycling have a comparative advantage over the production of the fresh one. In fact aluminium and glass can be recycled indefinitely, saving economic and environmental resources.

Waste Characteristics: A successful waste management depends on waste characteristics which are mainly waste surveying, and waste auditing. Wastes stream audit involves more detail assessment of waste. A waste audit can comprise all materials or focus on a particular waste type such as the paper or cardboard or hazardous waste as the case may be. 
Another method is the material flow method which tracks wastes based on unit quantity of waste deposited at a particular place per time. In such analysis, the usefulness of the waste can be considered and is recyclability examined. Waste composition differs from operation to operation; their identification and Classification are used in course of waste management.

Waste Classification: Waste can be classified into, municipal wastes, Industrial wastes, Hazardous wastes, Bio-degradable etc. Municipal wastes are wastes generated by household, commercial activities or other sources whose activities are similar to household or commercial activities (Tchobanoglous

et al 1993). Industrial wastes are from manufacturing industries. It comprises of many different streams arising from wide range of industrial process. Elisabeth (2004) opined that the largest wastes generating industrial sectors in Western and Central Europe are: basic metal, food, beverage and tobacco production industries, wood and wood products.

Hazardous wastes are those wastes whose uses or disposal pose threat to human health or the environment. They are wastes which have one or more of the following qualities. They could be toxic, corrosive explosive and/ or inflammable (Isirimah 2002). Some of these wastes could be found among the industrial, municipal or household wastes

Bio-degradable municipal wastes are those wastes that can be degraded by bacteria and fungi. example of these wastes are food wastes, garden wastes, paper, cardboard (US EPA 1995) etc. Agricultural wastes are composed of animal excreta in form of slurry, farmyard manure; spent mushroom compost stalks of cereal etc.

Packaging wastes are left over of products container. They are mostly non-degradable and they may have second-hand uses or recyclable qualities; examples are bottles, plastic container, aluminum, food rappers, drums etc.

Some waste management strategies:Recycling involves treatment or the processing of discarded waste material to make it suitable for subsequent reuse, either for its original form or for other purposes. It does not involve the use of virgin materials. Tierney (1996) reported that reuse of wastes depend on materials of the waste and that all wastes cannot be reused. Examples of materials to be recycled include discarded papers, glass, bottles etc. Wastes are first sorted into their end-use compatible groups. This helps in grouping them according to their uses. Waste could also be minimized; this involves the act of minimizing the quantity of wastes generated. There could also be waste reduction in which wastes are reduced to occupy smaller spaces, making it easier to transport Seo, (2004.)

Other ways of handling wastes are by composting. During composting, organic wastes are subjected to anaerobic digestion and used for agricultural purposes. Land filling is where wastes are disposed of into a pit, mostly burrow pit or mining pits; Incineration, involves thermal treatment of wastes. Other thermal treatment processes are pyrolysis and gasification. Goldstein and Mates (2001) identified air pollution and disposal of ash as the two concerns of incineration method.

\section{MATERIALS AND METHOD}

This study was a direct examination of dumpsite to appreciate the recycling potential of wastes along the East-west Road of Port Harcourt, from Choba Bridge to Rumukwurushi water tank. It also involved waste sorting examination and oral interviews.

During the study, a total of twenty scavengers (all male) between the ages of 18-45 years were interviewed to appreciate their different operating routes and to acknowledge the economic potentials of recyclable wastes.

Pictures of dumpsites were taken to have a rough estimate of wastes generated daily within this region. This informed the decision to fully characterize wastes and establish the recycling potential of these wastes. It was also seen that wastes were evacuated daily hence quantity of wastes found were roughly daily productions of each site.

\section{RESULTS AND DISCUSSION}

On the average it was found that the wastes were municipal wastes which were made up of items like papers, cardboards, cartons, aluminium plates, broken glasses, spoilt electronics, food wastes, peals of fruits, used clothing, pieces of metals from household, concretes from construction sites, hospital wastes, discarded computers hardware, ceramics plates etc.

Areas with concentrations of commercial activities were seen to produce greater quantities of solid wastes. These areas, in descending order of quantities of wastes found on site were: Rumudara, Choba Market, Rumukwurushi Tank, Rumuosi village, Bori Camp, Rumuokoro Market and University of Port Harcourt Teaching Hospital (UPTH) Junction. They 
were also noted for generation of packaging wastes and scrap materials. reduction cleaning and other value adding activities

. These were done to create some values for wastes.

Other activities by the scavengers observed include sorting, characterization, weighing repairing, size

Table 1. Components of wastes at different dump sites and their recycling potentials

\begin{tabular}{|c|c|c|c|}
\hline & SITES & COMPONENTS OF WASTES & RECYCLING POTENTIALS \\
\hline 1 & Choba Bridge & $\begin{array}{l}\text { Cartons, plastics aluminium, cans, paper, bottles, } \\
\text { glasses, ceramics plates, rubber attachments and } \\
\text { weavon }\end{array}$ & $\begin{array}{l}\text { Plastics can be recycled into fleece jackets, aluminium can be shredded, } \\
\text { ground and melted to produce molten aluminium. }\end{array}$ \\
\hline 2 & Choba Market & $\begin{array}{l}\text { Animal bones, cartons, plastics rubber, garbage, } \\
\text { papers, baskets and vegetable stems }\end{array}$ & $\begin{array}{l}\text { Cartons rubbers can be recycled into their original products. Vegetable } \\
\text { stems and garbage can be used as composts. Baskets can serve as fuel } \\
\text { for cooking }\end{array}$ \\
\hline 3 & UPTH Junction & $\begin{array}{l}\text { Kitchen wastes, nylon bags, papers, syringe, } \\
\text { needles, drip bags cotton wools. }\end{array}$ & $\begin{array}{l}\text { Kitchen wastes can be recycled into compost. Nylon bags, paper can be } \\
\text { recycled into their original products. }\end{array}$ \\
\hline 4 & Rumuosi Village & $\begin{array}{l}\text { Baskets, packaging materials, leather, tins, cans, } \\
\text { nylon bags, plastics, bottles, kitchen wastes, wood, } \\
\text { cartons etc }\end{array}$ & $\begin{array}{l}\text { Leather, plastic bottles cartons can be recycled into original products. } \\
\text { Sawdust from wood can be used to produce plywood, can also serve as } \\
\text { fuel. }\end{array}$ \\
\hline 5 & Rumuokoro Market & $\begin{array}{l}\text { Old fridges, computers, photocopying machines, } \\
\text { phones, wood, yard wastes, garbage, cartons, animal } \\
\text { bones, metal wires, food scraps, nylon bags, plastics } \\
\text { and old machines parts, }\end{array}$ & $\begin{array}{l}\text { Fridge, computer, photocopying machines television mobile phones } \\
\text { machines parts can be separately collected and sent to recycling plants } \\
\text { for dismantling and recycling into different related products. }\end{array}$ \\
\hline 6 & Bori Camp Gate & $\begin{array}{l}\text { Cartons Plastics leathers nylon bags kitchen wastes } \\
\text { tins, cans baskets, animal bones, glass, ceramics, } \\
\text { and aluminium }\end{array}$ & $\begin{array}{l}\text { Animal bones can be used for the manufacturing of vim. Kitchen wastes } \\
\text { can be recycled to produce biogas (methane). }\end{array}$ \\
\hline 7 & Rumuodara & $\begin{array}{l}\text { Plastics, cartons glass, old tyre, fridge papers wood } \\
\text { rubber, packaging materials, leathers, yard wastes } \\
\text { garbage animal bones, metal wires rags cloths tins } \\
\text { cans building roofing sheets old machines parts, } \\
\text { concretes. }\end{array}$ & $\begin{array}{l}\text { Clothes can be reused, garbage can be incinerated. They can also serve as } \\
\text { fuel. Concretes can be crushed into chips for construction of new houses. }\end{array}$ \\
\hline 8 & Rumukwurushi market & $\begin{array}{l}\text { Leather, animal bones, plastics, rubber, papers, old } \\
\text { machine parts, glasses, bottles, broken ceramics } \\
\text { plates, carton, yard wastes, garbage metals and old } \\
\text { furniture. }\end{array}$ & $\begin{array}{l}\text { Furniture can be re-used or its parts reconstructed into another wooden } \\
\text { work. Glasses and ceramics can be recycled into their original products }\end{array}$ \\
\hline
\end{tabular}

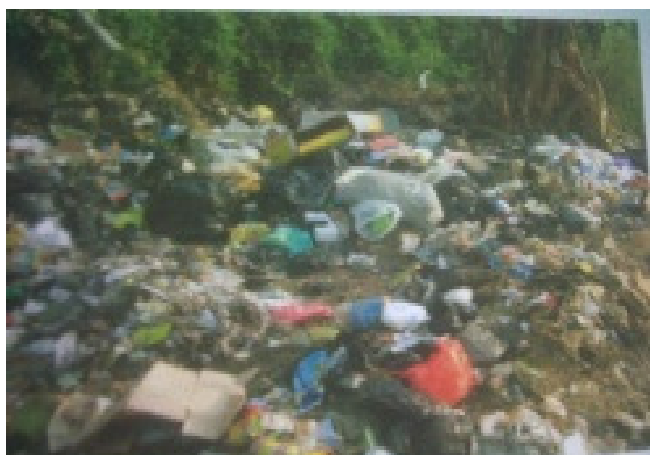

Plate 1: Choba bridge wastes receptacle

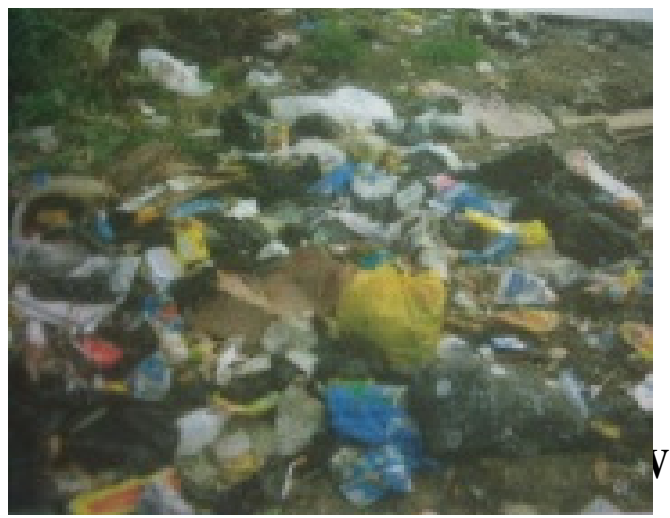

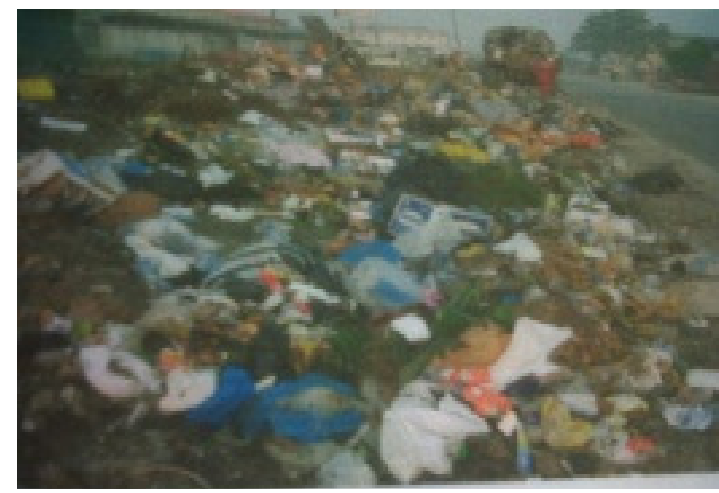

Plate 2: Choba market wastes receptacle

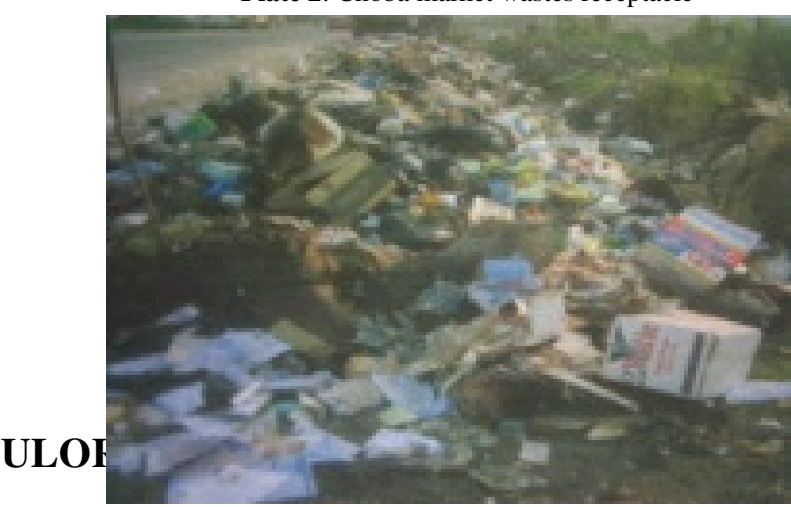


Plate 3 UPTH junction waste receptacle

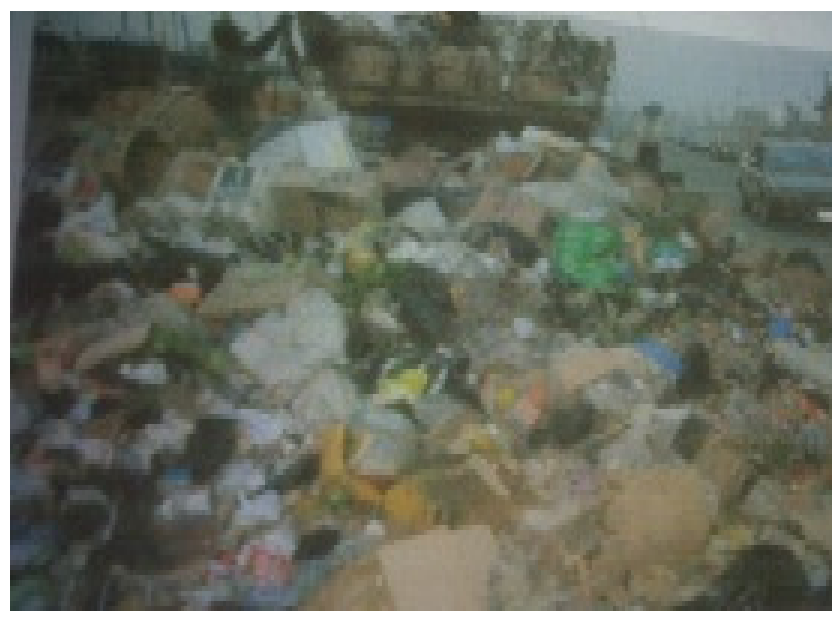

Plate 5 Rumuokoro market waste receptacle

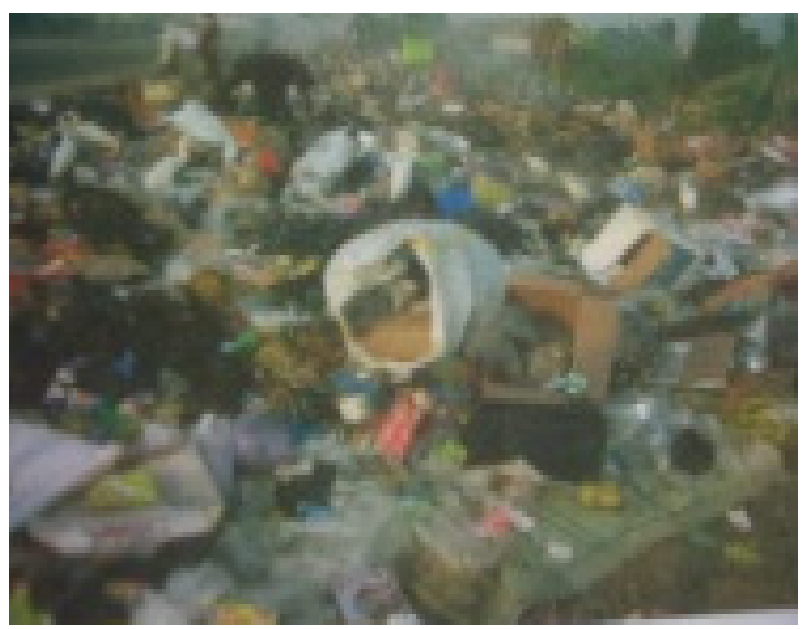

Plate 7 Rumuodara junction waste receptacle

Discussion: The different wastes have different values to enhance useful procedures for a developing country like Nigeria. Waste Papers were seen to be best recycled. This agrees with Matins (2002) who said that paper can be recycled seven times but they get shorter every time and eventually get strained out.

Plastics of different products are not recycled into the same product hence the plastics at the waste dump sites have to be fully examined to know which reusable qualities they will best fit into. Plastics must be nearly of identical composition to mix effectively. This could have contributed towards the
Plate 4: Rumuosi village waste receptacle

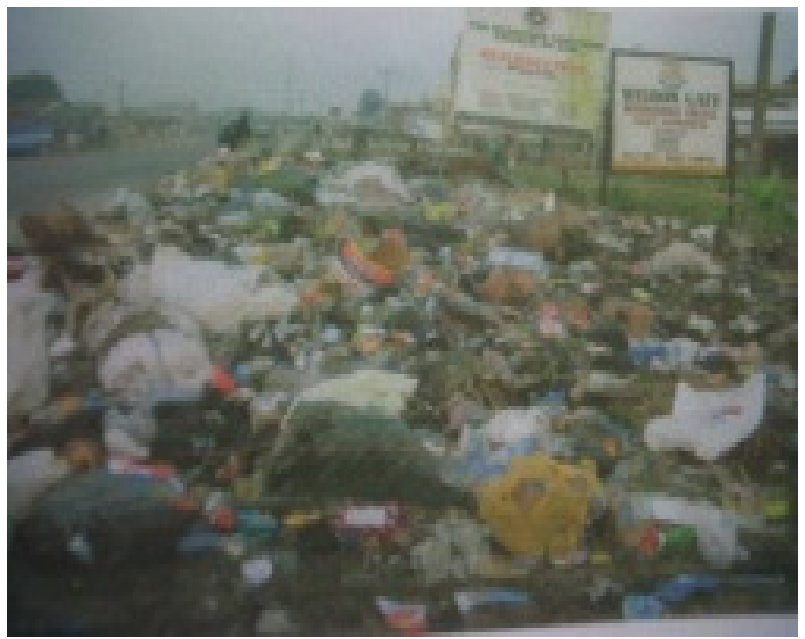

Plate 6: Bori camp waste receptacle

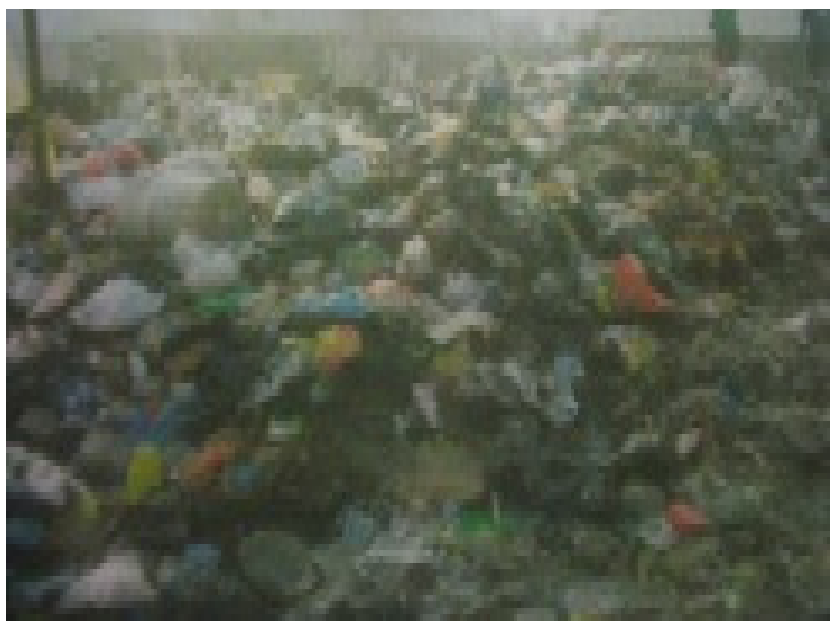

Plate 8: Rumuokwurusi Market waste receptacle

lager quantity of plastic at the waste dump site. When different types of plastic are molded together they tend to phase-separate (like oil and water) and the phase boundary cause structural weakness in the resulting material. And again plastics cannot be recycled into the same product from which they were recycled. These different constrains could have contributed to the poor patronage of some plastic materials by the scavengers.

Another barrier of recycling plastics is the widespread use of dyes and filler hence before plastic

KONYA, R. S; ZITTE, L. F.; UGWULOR, Q. N. 
are recycled, they are sorted according to their resin types because different plastics with different resin identification code are not mixed together. Plastics could also be heat treated and converted into quality fuel and carbon especially petroleum based plastics, through the process of pyrolysis RESEM (2013). This technology is not yet adopted in the country. Another method of plastic recycling was the used of different types of carbon sources in the recycling of scrap steel.

In Aluminium Recycling, there was relatively few aluminium plates found at the waste dump sites, rather, heavy bags of sorted aluminium were seen conveyed by the scavengers. This shows a great market for used scrap Aluminium. This agrees with what the Economist (2007) reported that recycling of aluminium requires only $5 \%$ of the energy used to make new aluminium and that it can be recycled indefinitely and still be used to produce any aluminium product.

There were some glasses found at the dump sites, nevertheless majority of glass wastes were recovered by the scavengers. This could be a pointer to the fact that there is a good glass recycling industry in the country, which is taking advantage of the rich resources of waste recycling to gain more profit in the business. Though, it was discovered that glass recycling involves a process of separating glass according to colours because glass retains its colour after recycling. Glass recycling uses less energy than manufacturing of glass from sand, lime and soda the Economist (2012). Every effort invested into glass recycling has a correspondingly higher profit because Every metric ton $(1000 \mathrm{~kg}$ ) of waste glass recycled into new item saves $315 \mathrm{~kg}(690 \mathrm{lb})$ of carbon dioxide from being released into the atmosphere during the creation of new glass (US EPA 2006). Recycling of glass save energy conserves raw material and reduces volume of waste sent to landfill British Standard Institute (2005)

Conclusion: Underdevelopment of Nigeria could be traced to poor waste recycling. This is because most of the products we have are only used once, hence, overtaxing the natural resources for fresh raw materials. The idea of waste management is not only for environmental pollution control purpose but also for economic development. We save more by waste recycling and waste more by using fresh raw materials. Lavee, (2007) reported that manufacturing companies have been recycling more wastes over the last 15 years.

Wastes on receptacles from Choba bridge to Rumukwurushi market have great recycling potentials which the scavengers found on sites were attempting to exploit. They took away recoverable items to Port Harcourt, Rivers State and Aba, Abia State of Nigeria and its environs for recycling. Metal and plastic items were most popular. Recycling should be encouraged as it can be a factor for reduction of poverty and transformation of the communities to commercial entities.

\section{REFERENCE}

Bonnie, Desimone (2006) Rewarding Recyclers and Finding Gold in garbage. New York Times Federal Environmental protection Agency, Market for Recovering retrieved 10 November 2006 ,

British Standard Institute (2005) PAS 101 Recovered Container Glass Specification for Quality and Guidance for Good Practices in Collection .

Daskalopoulus, E (1998) An Integrated Approach to Municipal Solid Waste Management . Journal of resources conservation and recycling 1.33-50

Elisabeth, Jeffries (2004) Recycling, Chartered Institute of Waste Management. The Journal for Professional Waste Managers July 2004 pg 1719

Goldstein N and Mates C (2001) the state of garbage in America Biocycle 12: 42-54

Gulphin A (1976) Dictionary of Environmental Terms Rout Age and Kegan Pau Limited London

Isirimah, Nnaemeka O. (2002) Understanding the Nature, Properties and Source of Waste for Quality Environment. Tome and Harry Publication Ltd Port Harcourt.

Lavee, D (2007) Municipal Solid Waste Recycling economically efficient environmental management

Matins, Sam (2004) paper chase ecology communication Retrieved 21 -09-2007.

\section{KONYA, R. S; ZITTE, L. F.; UGWULOR, Q. N.}


RESEM -Ruixin Environmental Specialty Equipment Manufacuring- (2013) China Plastic pyrolysis plant Retrieved 07-03-2013. Steel CNN Retrieved 09-11-06.

Seo, A (2004) Environmental impact of solid waste treatment methods in korea journal of Environmental Engineering 130(1); 81-89

Tchobanaglous G., H. Teisen and S. Vigil (1993); integrated solid waste management. Engineering principle.

The Economist (2007) Three Price of Virtue, Retrieved $7^{\text {th }}$ june 2007

The Economist (2012) Case History: the Truth about recycling retrieved May 7.2012

The price virtue the economist 07-06 -2007.
Tierney, John (1996) Recycling of Garbage, New York: New York Times p 3http://query NYtimes .com /gst / full page . html

US Environmental protection Agency (1990) Characterization of Municipal Solid Waste in the United State updated EPA 1530-SW-90-04 Washington D.C.

US Environmental protection Agency (1995) Process Design Manual, Surface Disposal of Sewage Sludge and Domestic septage EPA/ 625/R/-95022 Washington DC 20460

US Environmental protection Agency (2006) Glass Common Waste and Material: Glass Recycling Information Sheet, waste online .org. uk retrieved 26-11-2006.

KONYA, R. S; ZITTE, L. F.; UGWULOR, Q. N. 